\title{
Morphological Characterization of Ampelomyces spp., a Hyperparasite of Grapevine [Vitis vinifera (L.)] Powdery Mildew
}

\author{
M. Banupriya ${ }^{1}$, C. Ushamalini ${ }^{2 *}$, S. Nakkeeran ${ }^{1}$ and T. Raguchander $^{1}$ \\ ${ }^{1}$ Department of Plant Pathology, Tamil Nadu Agricultural University, Coimbatore - 641003, \\ Tamil Nadu, India \\ ${ }^{2}$ Coconut Research Station, TNAU, Aliyar Nagar, Tamil Nadu Agricultural University, \\ Coimbatore - 641003, Tamil Nadu, India \\ *Corresponding author
}

\section{A B S T R A C T}

\begin{tabular}{|l|}
\hline Ke y w or d s \\
Ampelomyces, \\
Erysiphales, Grape, \\
Pycnidia, \\
Hyperparasite
\end{tabular}

\section{Introduction}

Grapevine is one of the most important fruit crop and belongs to the family Vitaceae. It is basically a sub-tropical crop. However, in India, grapes are cultivated under tropical conditions also this crop is grown throughout the world for wine making ( $82 \%$ production), raisin making (10\% production) and rest for table purpose $(8 \%)$. In India, although it is mostly consumed as fresh fruit and only a limited quantity is utilized for the production of wine, dry fruits like raisins etc.
Survey was conducted in grapevine growing areas of Coimbatore district during October to December 2018 to assess the incidence of powdery mildew and to collect different isolates of Ampelomyces spp. The powdery mildew incidence was noticed from 14.65 to 63.21 PDI. Ten isolates of Ampelomyces spp. were collected from powdery mildew infected grapevine leaf parasitized by Ampelomyces spp. All the isolates were identified by their morphological characters. Most of the isolates showed flat and radial growth pattern with raised growth of mycelia brownish black to greyish white. The pycnidia of different isolates of Ampelomyces varied in their shape and were mostly ovoid, ellipsoid, indrical, spindle, pyriform to globose in shape. Ampelomyces spp. was studied for its morphological characters in the present work. 
caused by Erysiphaceae family. Due to its wide host range, the mycoparasite is a highly promising candidate for biological control, as it is highly specific to powdery mildews. To study its morphological characters, this study was undertaken.

\section{Materials and Methods}

Survey for the incidence of powdery mildew in grapevine cultivating areas

A roving survey was conducted in major grapes cultivating areas in Coimbatore district of Tamil Nadu viz., Theethipalayam, Madampatti, Mathipalayam, Kuppanur, Devarayapuram, Boluvampatti, Thenkarai, Alanthurai, TNAU Orchard and Deenampalayam during October-December 2018 for assessing the incidence of powdery mildew of grapes. During the survey, a Global Positioning System (GPS) was used to determine the coordinates precisely for each field visited. In each village three farmer's fields were selected and in each farmers field, at three places 20 plants were selected at random and in each plant the per cent leaf area of the grapes affected by powdery mildew was assessed visually by following the 0-9 scale (Azmat et al., 2012; Nongmaithem et al., 2017). The disease score was converted to Per cent Disease Index (PDI) by following the formula given by Wheeler (1969). The Per cent Disease Index is worked out as described by Mc Kinney's (1923)

\section{Isolation of Ampelomyces spp.}

The grapevine leaves showing typical powdery mildew symptoms and hyperparasitized by Ampelomyces spp. were collected from farmer's field in different areas of Coimbatore district. The powdery mildew infected grapevine leaves hyperparasitized by Ampelomyces spp. appearing as ash to dark brown in colour collected in polythene bags and brought to the laboratory and preserved in an incubator at $25^{\circ} \mathrm{c}$ for further studies.

Immediately after examination under image analyzer one or two pycnidia were separated with sterile needles from the powdery mildew fungal propagules and these pycnidia were placed in $2 \%$ water agarose medium $(\mathrm{Gu}$ and Ko, 1997) for conidial germination of Ampelomyces spp. After 4-5 days, the emerging colonies were quickly transferred to Potato Dextrose Agar (PDA) supplemented with 0.5 per cent chloramphenicol and 1 per cent of streptomycine sulphate $(10,000$ I.U. $\mathrm{ml}^{-1}$ ) under aseptic conditions.

Pure cultures were maintained in PDA at room temperature $\left( \pm 25^{\circ} \mathrm{c}\right)$ and transferred at every 6-8 weeks to new Petri plates. Before isolation, the pycnidia and pycnidiospores were observed for confirmation of Ampelomyces spp. using stereomicroscope.

\section{Morphological characters of the isolates of Ampelomyces spp.}

The different isolates of Ampelomyces spp. were grown in potato dextrose agar medium by placing a disc of the actively growing mycelium in the centre of the Petri dish and incubated at room temperature. Ampelomyces spp. is identified based on morphological characters of the pycnidia and pycnidiospore.

\section{Results and Discussion}

\section{Survey for the powdery mildew incidence of grapevine}

The results revealed that the per cent disease index (PDI) of powdery mildew in Coimbatore district was ranged from 14.65 to 63.21 PDI. The maximum disease incidence of 63.21PDI was observed at Theethipalayam village followed by 52.24 PDI at Alanthurai 
village and minimum incidence of 14.65 PDI was recorded at Devarayapuram village in Coimbatore district (Table 1). The present study revealed that, the incidence of powdery mildew disease showed its wide spread occurrence in almost all grape growing areas of Coimbatore district. The incidence of powdery mildew upto 32.61 to 45.55 and 14.08 to 20.84 per cent in leaves and pods was reported by Parthasarathy et al., 2017.

\section{Collection of Ampelomyces spp.}

The hyperparasite Ampelomyces spp. was isolated and the isolate number was given for each isolates collected from Thondamuthur block of Coimbatore district (Table 1). In this present study, ten isolates of Ampelomyces spp. was isolated from the powdery mildew infected grapevine leaves. This was in accordance with the previous study conducted by Angeli et al., (2009b) where they have isolated Ampelomyces spp. by transferring the conidia onto potato dextrose agar which was amended with $2 \%$ chloramphenicol by using tissue segment method. The fungal growth was observed and purified by hyphal tip culture technique and maintained on PDA slants at $5^{\circ} \mathrm{C}$. Liang et al., (2007) removed one or two pycnidia from the mildew mycelia and transferred to potato dextrose agar (PDA) supplemented with $0.5 \%$ chloramphenicol.

Table.1 Survey for the incidence of powdery mildew and collection of isolates of Ampelomyces spp. in major grape growing areas of Coimbatore district

\begin{tabular}{|c|c|c|c|c|c|c|c|}
\hline S. No & $\begin{array}{l}\text { Place of } \\
\text { collection }\end{array}$ & Stage of crop & $\begin{array}{l}\text { Variety/ } \\
\text { Hybrid } \\
\text { cultivated }\end{array}$ & $\begin{array}{l}\text { Latitude } \\
\text { (N) }\end{array}$ & $\begin{array}{l}\text { Longitude } \\
\text { (E) }\end{array}$ & $\begin{array}{c}\text { Mean } \\
\text { PDI of } \\
\text { powdery } \\
\text { mildew }\end{array}$ & $\begin{array}{c}\text { Isolates of } \\
\text { Ampelomyces } \\
\text { spp. }\end{array}$ \\
\hline 1. & Mathipalayam & Flowering & $\begin{array}{l}\text { Muscat } \\
\text { Hamburg }\end{array}$ & $10.9327^{\circ}$ & $76.8415^{\circ}$ & $35.80^{\mathrm{e}}$ & TNAU-AQ101 \\
\hline 2. & Madampatti & Flowering & $\begin{array}{l}\text { Muscat } \\
\text { Hamburg }\end{array}$ & $10.9698^{\circ}$ & $76.8598^{\circ}$ & $29.35^{\mathrm{g}}$ & TNAU-AQ102 \\
\hline 3. & Deenam & Flowering & $\begin{array}{c}\text { Muscat } \\
\text { Hamburg }\end{array}$ & $11.0044^{\circ}$ & $76.8572^{\circ}$ & $32.28^{\mathrm{f}}$ & TNAU-AQ103 \\
\hline 4. & Theethipalayam & Flowering & $\begin{array}{c}\text { Muscat } \\
\text { Hamburg }\end{array}$ & $10.9523^{\circ}$ & $76.8865^{\circ}$ & $63.21^{\mathrm{a}}$ & TNAU-AQ104 \\
\hline 5. & Kuppanur & Flowering & $\begin{array}{l}\text { Muscat } \\
\text { Hamburg }\end{array}$ & $10.9478^{\circ}$ & $76.8627^{\circ}$ & $46.47^{\mathrm{c}}$ & TNAU-AQ105 \\
\hline 6. & Devarayapuram & Flowering & Red globe & $10.9976^{\circ}$ & $76.8159^{\circ}$ & $14.65^{\mathrm{j}}$ & TNAU-AQ106 \\
\hline 7. & The & & Red globe & $10.9366^{\circ}$ & 76.8 & $43.73^{d}$ & TNAU-AQ107 \\
\hline 8. & TNAU, Orchard & Flowering & $\begin{array}{l}\text { Muscat } \\
\text { Hamburg }\end{array}$ & $10.9009^{\circ}$ & $76.7856^{\circ}$ & $52.24^{\mathrm{b}}$ & TNAU-AQ108 \\
\hline 9. & Alanthurai & Flowering & Red globe & $11.0098^{\circ}$ & $76.8487^{\circ}$ & $18.49^{\mathrm{i}}$ & TNAU-AQ109 \\
\hline 10. & Boluvampatti & Flowering & $\begin{array}{c}\text { Muscat } \\
\text { Hamburg }\end{array}$ & $10.9921^{\circ}$ & $76.7221^{\circ}$ & $24.40^{\mathrm{h}}$ & TNAU-AQ110 \\
\hline
\end{tabular}

*PDI- Per cent Disease Index, * Values are means of three replications, Means followed by a common letter are significantly different at $5 \%$ level by DMRT 
Table.2 Morphological characters of different isolates of Ampelomyces spp. on potato dextrose agar medium

\begin{tabular}{|c|c|c|c|c|c|c|c|}
\hline S. No & Isolates & Mycelium & Topography & $\begin{array}{c}\text { Colour of } \\
\text { mature } \\
\text { colonies }\end{array}$ & Zonation & Margin & $\begin{array}{c}\text { Colony } \\
\text { growth }\end{array}$ \\
\hline $\mathbf{1 .}$ & $\begin{array}{c}\text { TNAU- } \\
\text { AQ101 }\end{array}$ & $\begin{array}{c}\text { Septate, } \\
\text { hyaline }\end{array}$ & Radial & $\begin{array}{c}\text { Greyish } \\
\text { white }\end{array}$ & Absent & Irregular & Slow \\
\hline $\mathbf{2 .}$ & $\begin{array}{c}\text { TNAU- } \\
\text { AQ102 }\end{array}$ & $\begin{array}{c}\text { Septate, } \\
\text { hyaline }\end{array}$ & Flat & Ash & Absent & Smooth & Slow \\
\hline $\mathbf{3 .}$ & $\begin{array}{l}\text { TNAU- } \\
\text { AQ103 }\end{array}$ & $\begin{array}{l}\text { Septate, } \\
\text { hyaline }\end{array}$ & Flat & Brown & Present & Wavy & Moderate \\
\hline $\mathbf{4 .}$ & $\begin{array}{l}\text { TNAU- } \\
\text { AQ104 }\end{array}$ & $\begin{array}{l}\text { Septate, } \\
\text { hyaline }\end{array}$ & Radial & White & Absent & Wavy & Very slow \\
\hline $\mathbf{5 .}$ & $\begin{array}{l}\text { TNAU- } \\
\text { AQ105 }\end{array}$ & $\begin{array}{l}\text { Septate, } \\
\text { hyaline }\end{array}$ & Appressed & $\begin{array}{c}\text { Brownish } \\
\text { black }\end{array}$ & Absent & Smooth & Slow \\
\hline $\mathbf{6 .}$ & $\begin{array}{l}\text { TNAU- } \\
\text { AQ106 }\end{array}$ & $\begin{array}{l}\text { Septate, } \\
\text { hyaline }\end{array}$ & Flat & $\begin{array}{c}\text { Brownish } \\
\text { black }\end{array}$ & Present & Irregular & Very slow \\
\hline $\mathbf{7 .}$ & $\begin{array}{l}\text { TNAU- } \\
\text { AQ107 }\end{array}$ & $\begin{array}{l}\text { Septate, } \\
\text { hyaline }\end{array}$ & Radial & White & Absent & Smooth & Moderate \\
\hline $\mathbf{8 .}$ & $\begin{array}{l}\text { TNAU- } \\
\text { AQ108 }\end{array}$ & $\begin{array}{l}\text { Septate, } \\
\text { hyaline }\end{array}$ & Radial & Brown & Absent & Wavy & Slow \\
\hline $\mathbf{9 .}$ & $\begin{array}{l}\text { TNAU- } \\
\text { AQ109 }\end{array}$ & $\begin{array}{l}\text { Septate, } \\
\text { hyaline }\end{array}$ & Radial & Greyish & Present & Smooth & Moderate \\
\hline $\mathbf{1 0 .}$ & $\begin{array}{l}\text { TNAU- } \\
\text { AQ110 }\end{array}$ & $\begin{array}{l}\text { Septate, } \\
\text { hyaline }\end{array}$ & Radial & Brown & Absent & Wavy & Moderate \\
\hline
\end{tabular}

Table.3 Pycnidial characters of different isolates of Ampelomyces spp. on potato dextrose agar medium

\begin{tabular}{|c|c|c|c|c|}
\hline S. No & Pycnidia & $\begin{array}{c}\text { Pycnidial size } \\
(\boldsymbol{\mu m})^{*}\end{array}$ & $\begin{array}{c}\text { Pycnidiospore } \\
\text { Pycnidiospore size } \\
(\boldsymbol{\mu m})^{*}\end{array}$ \\
\hline $\mathbf{1 .}$ & Spherical & $115.66 \times 100.39$ & Unicellular, hyaline, Oval & $3.12 \times 1.67$ \\
\hline $\mathbf{2 .}$ & Pyriform & $64 . .62 \times 57.67$ & Unicellular, hyaline, Round & $4.13 \times 1.23$ \\
\hline $\mathbf{3 .}$ & Globose & $80.73 \times 73.7$ & Unicellular, hyaline, Oval & $4.45 \times 2.5$ \\
\hline $\mathbf{4 .}$ & Round & $60.78 \times 56.67$ & Unicellular, hyaline, Oval & $5.87 \times 2.36$ \\
\hline $\mathbf{5 .}$ & Oval & $68.18 \times 55.15$ & Unicellular, hyaline, Round & $6.78 \times 3.9$ \\
\hline $\mathbf{6 .}$ & Globose & $82.18 \times 68.18$ & Unicellular, hyaline, Oval & $4.97 \times 3.2$ \\
\hline $\mathbf{7 .}$ & Ovoid & $60.46 \times 24.5$ & Unicellular, hyaline, Round & $3.52 \times 2.1$ \\
\hline $\mathbf{8 .}$ & Spherical & $66.66 \times 58.8$ & Unicellular, hyaline, Oval & $5.45 \times 1.49$ \\
\hline $\mathbf{9 .}$ & Spindle & $76.9 \times 24.7$ & Unicellular, hyaline, Round & $5.5 \times 3.8$ \\
\hline $\mathbf{1 0 .}$ & Pear & $89.16 \times 24.5$ & Unicellular, hyaline, Round & $4 \times 3.2$ \\
\hline
\end{tabular}

$*$ Values are means of three replications 
Plate.1 Morphological characters of different isolates of Ampelomyces spp. on potato dextrose agar medium

A
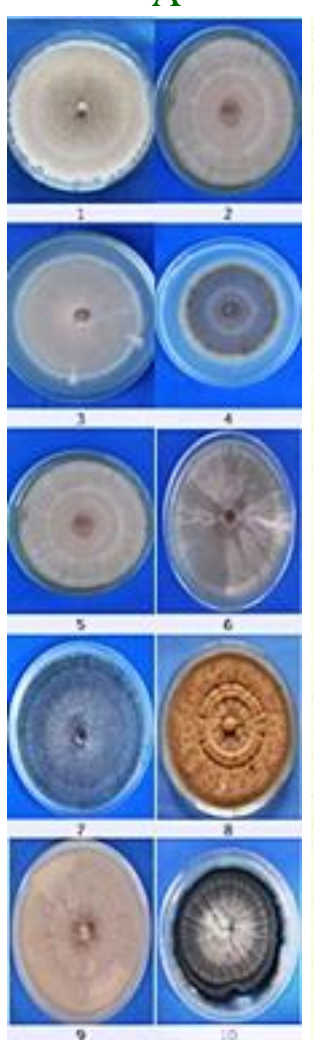

B
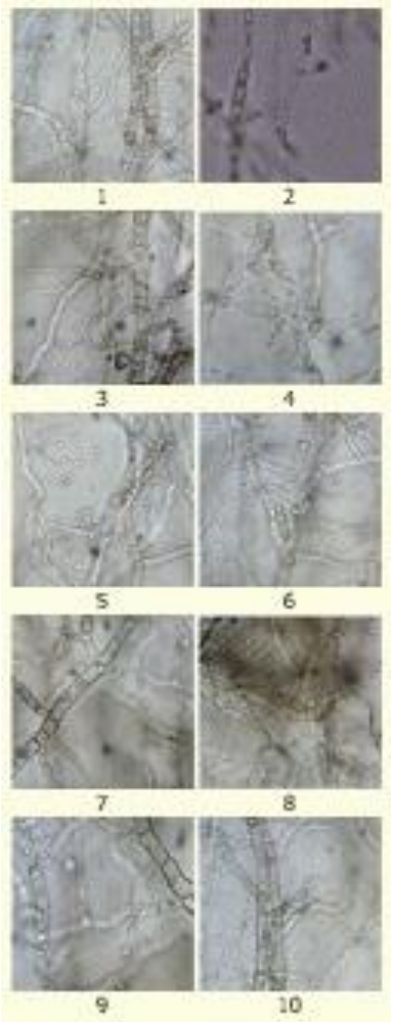

$\mathrm{C}$
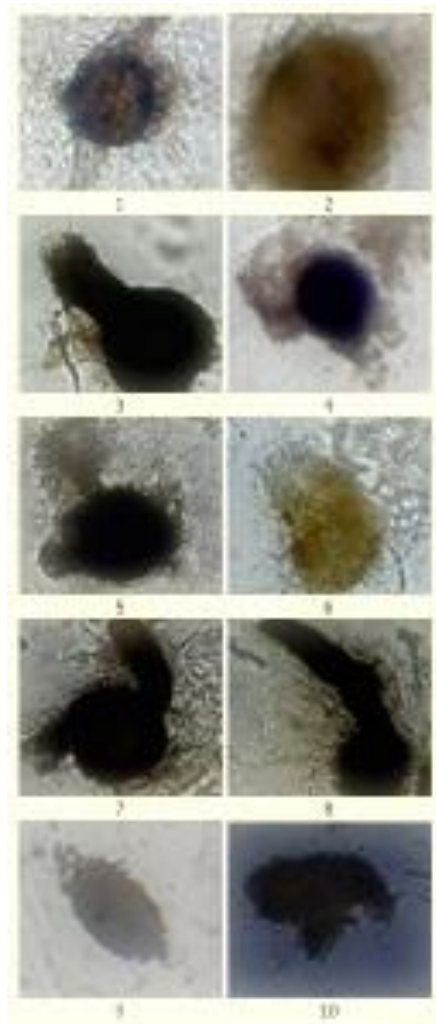

$\mathrm{D}$
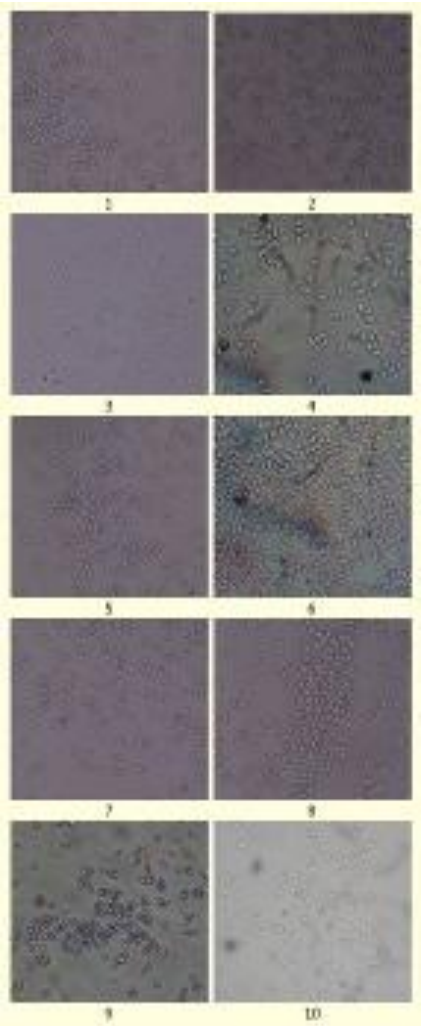

A- Isolates, B- Mycelium, C- Pycnidia, D- Pycnidiospore 1-TNAU-AQ101, 2-TNAU-AQ102, 3- TNAU-AQ103, 4-TNAU-AQ104, 5-TNAU-AQ105, 6-TNAU-AQ106, 7TNAU-AQ107, 8-TNAU-AQ108, 9- TNAU-AQ109, 10-TNAU-AQ110

Morphological growth characters of isolates of Ampelomyces spp.

The morphological character of different isolates of Ampelomyces spp. viz., mycelium, topography, colour, margin of colonies, zonation, colony growth, pycnidial shape and size, pycnidiospore shape and size were studied. In general the mycelia were septate and hyaline in nature. The topography of the each isolates varied from radial, appressed and flat. The colour of mature colonies was also varied as greyish white, brownish black, ash, brown and white in nature. Zonation was observed in some isolates like TNAU-AQ103, TNAU-AQ106 and TNAU-AQ109. The pycnidia of different isolates of Ampelomyces spp. varied in their shape. Pycnidia were light to dark brown in colour, non-ostiolate and were mostly pyriform, globose, spherical, ovoid, pear, spindle, oval and round in shape. In general the pycnidia measured about 60.46$115.66 \times 24.7-100.39 \mu \mathrm{m}$ (Table 2, plate 1). This was in accordance with Liang et al., (2007) who reported that the pycnidia were pyriform to globose measuring about 36-123 $\times 22-45 \mu \mathrm{m}$. Similar results were reported by Kim et al., (2009) who reported that the colour of pycnidium ranged from light brown to dark brown. Angeli et al., (2009b) revealed that the pycnidia of Ampelomyces spp. varied in shape depending upon the fungal structure in which they were formed. They were pearshaped, spindle-shaped or nearly spherical when they were formed inside E. necator conidiophores, hyphae or chasmothecia. 
Pycnidiospores were hyaline, one-celled and oval to round in shape measuring 3.12-6.78 $\times$ $1.23-3.9 \mu \mathrm{m}$. The results agree with Kiss (2008) who reported that the conidia of Ampelomyces spp. were found to be unicellular, hyaline and guttulate in shape measuring about 11.5 to $14.5 \mu \mathrm{m}$ in length (major axis) and 2.5 to $3.5 \mu \mathrm{m}$ in width (minor axis). Liang et al., (2007) also reported that pycnidia of Ampelomyces spp. contained unicellular guttulate conidia which measured about 4.2-7.5 × 2-3.6 $\mu \mathrm{m}$. Angeli et al., (2009b) also revealed that the conidial shape of $A$. quisqualis were fusiform to ellipsoid and their size varied from 11.5 to $14.5 \mu \mathrm{m}$ in length and 2.5 to $3.5 \mu \mathrm{m}$ in width (Table 3).

The present study revealed that, the incidence of powdery mildew disease showed its wide spread occurrence in almost all grape growing areas of Coimbatore district. The per cent disease index (PDI) of powdery mildew ranged from 14.65 to $63.21 \mathrm{PDI}$. The isolates of Ampelomyces spp vary in their morphological characters i.e., colony colour (ash to brownish black), zonation, pycnidial shape (globose to pyriform) and pycnidiospores size (3.12-6.78 × 1.23-3.9 $\mu \mathrm{m})$. By studying the antibiotic nature of these isolates, effective isolate may be exploited in the biocontrol of powdery mildew pathogen in future.

\section{References}

Aly, AH, Edrada-Ebel, RA, Wray, V, Muller, WEG, Kozitskaya, S, Hentschel, U, et al., Bioactive metabolites from the endophytic fungus Ampelomyces sp. isolated from the medicinal plant Urospermum picroides. Phytochemistry, 2008; 69: 1716-1725.

Angeli, D, Pellegrini, E and Pertot, I. Occurrence of Erysiphe necator chasmothecia and their natural parasitism by Ampelomyces quisqualis. Phytopathology. 2009b; 99:704-710.

Athira, K, Ragupathi, N and Raguchander, T. Morphological characterization of Ampelomyces spp. a hyperparasite of Bhendi (Abelmoschus esculentus (L.) Moench) powdery mildew. Journal of Applied and Natural Science 2017; 9 (4): 1954 -1957

Azmat, MA, Khan, AA, Saeed, A, Ashraf, M and Niaz, S. Pathogenicity and characterization of geographically distributed isolates of Erysiphe polygoni. Int. J. Veg. Sci.2012; 18: 211222.

Dry, IB, Feechan, A, Anderson, C, Jermakow, AM, Bouquet, A, Adam-Blondon, AF, Thomas, MR, Molecular strategies to enhance the genetic resistance of grapevines to powdery mildew. Aust. J. Grape Wine Res. 2010; 16, 94-105.

$\mathrm{Gu}, \mathrm{YH}, \mathrm{Ko}, \mathrm{WH}$, Water agarose medium for studying factors affecting germination of conidia of Ampelomyces quisqualis. Mycol. Res. 1997; 101, 422-424.

Kim, JY, Lee, WH and Kim, HM. Physical Characteristics and Antagonistic Effect of Ampelomyces. Research in Plant Disease. 2009; 15: 209-216.

Kiss, L \& Nakasone, KK. Ribosomal DNA internal transcribed spacer sequences do not support the species status of Ampelomyces quisqualis, a hyperparasite of powdery mildew fungi. Current Genetics. 1998; 33, 362-367.

Kiss, L. A review of fungal antagonists of powdery mildews and their potential as biocontrol agents. Pest Management Science. 2003; 59, 475-483.

Kiss, L. Intracellular mycoparasites in action: interactions between powdery mildew fungi and Ampelomyces. British Mycological Society Symposia Series. 2008; 37-52.

Liang, C, Yang, J, Kovacs, GM, Szentivanyi, $\mathrm{O}, \mathrm{Xu}, \mathrm{X}$ and Kiss, L. Genetic diversity 
of Ampelomyces mycoparasites isolated from different powdery mildew species in China inferred from analyses of rDNA ITS sequences. Fungal Diversity. 2007; 24:225-240.

Mckinney, H. A new system of grading plant diseases. J. Agric. Res. 1923; 26:195218.

Parthasarathy, S, Muthamilan, M, Harish, S, Alice, D and Raguchander, T. Natural incidence and genetic variability of Erysiphe pisi, the causal agent of Powdery mildew on peas in the Nilgiris district, Tamil Nadu, India, Current
Journal of Applied Science and Technology. 2017; 24(5): 1-11.

Paulitz, TC and Belanger, RR. Biological control in greenhouse systems. Annual Review of Phytopatholo-gy. 2001; 39: 103-133.

Sundheim, L and krekling, T. Host-parasite relationships of the hyperparasite Ampelomyces quisqualis and its powdery mildew host Sphaerotheca fuliginea. Journal of Phytopathology. 1982; 104, 202-210.

\section{How to cite this article:}

Banupriya, M., C. Ushamalini, S. Nakkeeran and Raguchander, T. 2019. Morphological Characterization of Ampelomyces spp., a Hyperparasite of Grapevine [Vitis vinifera (L.)] Powdery Mildew. Int.J.Curr.Microbiol.App.Sci. 8(06): 1725-1731. doi: https://doi.org/10.20546/ijcmas.2019.806.206 